\title{
East Meets West: An East Indian Coin in the Western Colonies
}

\author{
Kiara Beaulieu ${ }^{1}$
}

Published online: 24 October 2016

(C) The Author(s) 2016. This article is published with open access at Springerlink.com

\begin{abstract}
In 1823, the Ontario House, a hotel and tavern, was built near Niagara Falls, Canada. In addition to providing a location for travelers and tourists to drink and lodge, Ontario House, like many other establishments, billeted soldiers when the need arose. The 2012 excavation of the midden and features of the Ontario House produced a large assemblage of artifacts including ceramics, buttons, numismatics, and military accoutrements. Of particular interest is an East Indian coin, found in the natural topsoil, which can be associated with the 67th Regiment of Foot's brief occupation of Ontario House in 1841. This paper addresses the significance of this coin and associated finds in regards to the global movement of the regiment and the socio-political context of Ontario House within regional history.
\end{abstract}

Keywords Military $\cdot$ Canada $\cdot$ Numismatics $\cdot$ Rebellion crisis

\section{Introduction}

This paper will examine one small find uncovered during the excavation of the Loretto site (AgGs-326) in Niagara Falls, Ontario during the fall of 2012 by Archaeological Services Inc. (Hull and MacDonald 2014). The site contained features related to three different structures occupied at different times, including the Ontario House (1823-59), a hotel and tavern in close proximity to the Falls (Fig. 1) that was part of a vibrant history for which little has been recorded. One notable find, amongst many, from the Ontario House midden was an East Indian pai sikka. Three theories that explain how the pai sikka came to be deposited in Niagara Falls will be presented. These theories

Kiara Beaulieu

kiarabeaulieu@gmail.com

1 Department of Classics, Ancient History, and Archaeology, University of Birmingham,

Birmingham, UK 


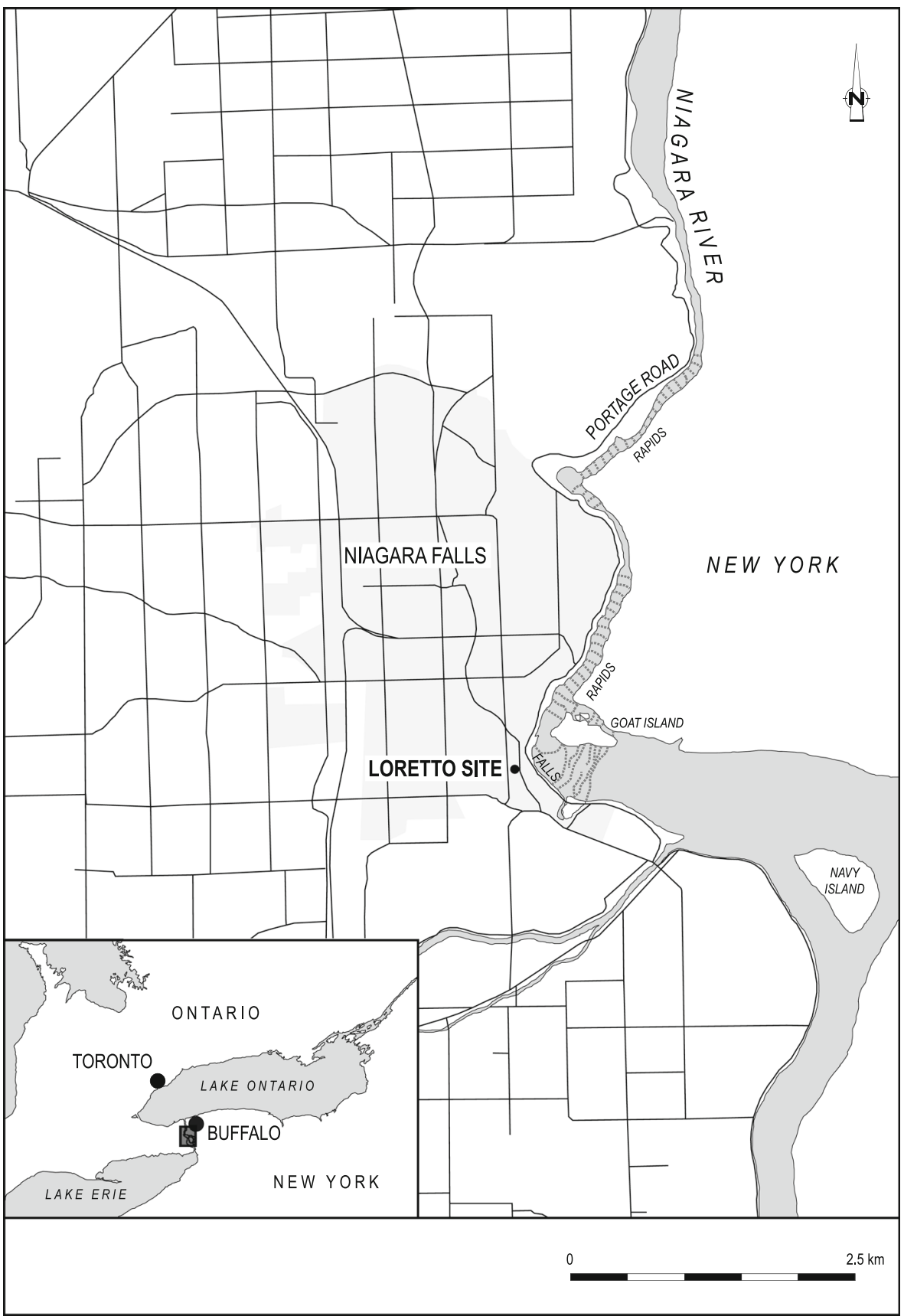

Fig. 1 The location of the Loretto site in the city of Niagara Falls, Ontario (Map by David Robertson)

will identify the global movement of British troops during the nineteenth century, the context of the Ontario House within regional tourism, and the significance of this find in regard to the scarcity of specie in the colonies during this time. 


\section{The Coin}

The Loretto Site (AgGs-326) yielded a large number of military and commercial items, as well as those of a more personal nature, including five coins; two were badly damaged and three could be identified although they presented with varying degrees of wear. Of the three, one specimen stood out as a truly fascinating piece: a full pai sikka. The pai sikka or pice is a coin of the Bengali Presidency and the Calcutta Mint began its production in 1795. The pice was considered legal tender in the three provinces of Lower Bengali (Pridmore 1975, p. 210). The script on the obverse (Fig. 2, left) is the name of the Mughal Emperor, Shah Alam Badshah II (1728-1806). The second line reads sanat julus 37 , which refers to the 37 th year of his reign, in Islamic years. The 37th year of his reign began on 3 November 1794 and concluded 22 October 1795 (Pridmore 1975, p. 209). The East India Company, the issuing body, kept issuing the pai sikka with the name Shah Alam Badshah II and a frozen year (19, and 37 seem to be most popular) until 1831, when the copper pice was redesigned by the mint master R. Saunders (Pridmore 1975, p. 213) and it no longer resembled the Mughal variety.

The reverse (Fig. 2, right) gives the denomination one paisa in Bengali (top 2 lines), Urdu (3rd; Persian script), and Hindi (bottom 2 lines; devanagari script). The Bengali is an older version of the script so it uses a quite different set of characters and spelling conventions than would normally have been used at the time (Holt Parker, pers. comm.). The three languages were used in the different parts of the provinces where the pai sikka was circulated: Bengal, Bihar, and Orissa (Stevens 2012, p. 159). The term sikka means coin, so what was uncovered is a one pai sikka. Other denominations include the half pai sikka, a two and even a three pai sikka. One of the few primary sources that discuss the pice is the Rev. Rogers Ruding's book Annals of the Coinage of Great Britain and its Dependencies. He noted that "the Pice, or copper coin of Bengal, has undergone various modifications, as well as the gold and silver. The first were coined, by contrast, in 1782, but they were struck in the mint of Calcutta from the year 1792. At first they bore the date on one side and a shield on the other; but from 1795 they were stamped with legends in the native language" (Ruding 1840, p. 420).

Three regulations were laid out by the Governor General, Sir John Shore in 1795 for the proposed copper coinages (Revenue Consultations, October 2, 1795, IOR P/89/32.2,
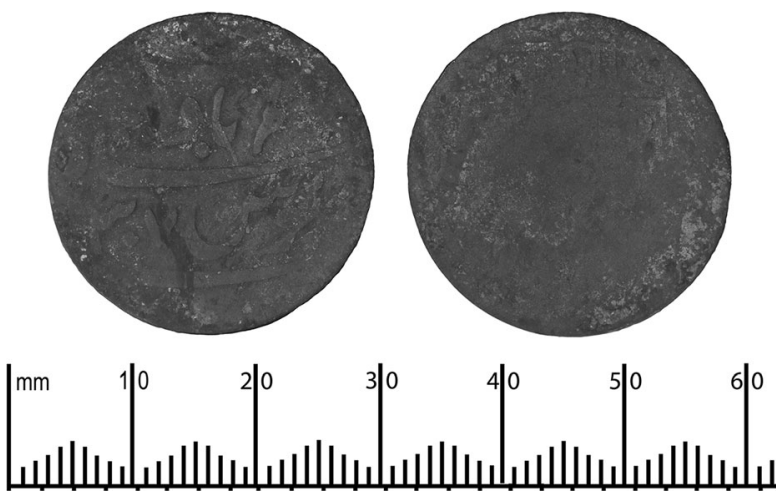

Fig. 2 The 1 pai sikka found at the Loretto site (Photograph by John Howarth, courtesy of Archaeological Services Inc) 
No. 388) including which languages were to be inscribed on the coins, their value, and which mint was authorized to produce them. As mentioned above, the sanat julus 37 references the 37th year of the reign of Shah Alam Bashad II and was also the year that the copper pice was approved. In November 1795, the mint master, James Miller, struck two denominations to find out which version would be in the highest demand. Originally the values were quarter anna, or an eighth anna, however, it was altered a few days later to one pai sikka and a half pai sikka as it was thought that the latter conventions would be understood by a greater audience (Pridmore 1975, p. 209). For the brief period that the pice was in production, Calcutta was the only mint to legally produce copper coinage for the provinces. However, this changed dramatically when coinage was authorized to be produced at the Benares mint in 1815 (Bengal Mint Committee Proceedings (1816) IOR $\mathrm{P} / 162 / 69$, No. 159) and the Farrukhabad mint in 1816 (Bengal Consultations, November 9, 1816, IOR P/9/17, No. 17). In 1817, a regulation was put forth that the pice, struck at any of the three mints, was considered valid currency throughout the Presidency (Bengal Mint Committee Proceedings IOR P/162/70, No. 46).

The dating of the pice is a difficult task; many organizations choose to provide a blanket date in order to provide chronological placement for these pieces. The Fitzwilliam Museum dates this coin, and all pai sikka, from 1759 to 1806, intending to show that they were issued after the death of Shah Alam Bashad II (M. Allen, pers. comm.). The frozen dates were meant as a countermeasure to combat the devaluation of coins by Indian money changers or shroffs. These money changers would charge a batta where they would reduce the value of a piece depending on year, some could be devalued up to $13 \%$ in order to exchange it for better quality or newer pieces (Stevens 2012, p. 26). By not including specific years on the coins, the East India Company could retain a stronger hold on the value of coins minted (Stevens 2012, p. 27). Firmer dates may be ascertained by the diameter and weight of the coin, however, wellcirculated or archaeological specimens may weigh less or more than the standard.

The Ontario House pai sikka's diameter fits nicely at $25.8-25.9 \mathrm{~mm}$ with the date for 1809. Its weight is a slight $5.65 \mathrm{~g}$ for the full pai sikka, but fits into the range of the early (1795) half pice. Even though this pice is badly worn on the reverse, some details can be ascertained to help identify which version was uncovered, the remaining inscriptions indicate that this piece is indeed the full and not the half variety. The reverse is more badly damaged than the obverse, however, a few portions of the inscription are visible, which, when coupled with the obverse inscription, help in identifying the year. Although the Ontario House pai sikka would closely fit the weight of KM\# 29 in The Standard Catalogue of World Coins 1801-1900 (Krause and Mischler 2004), the visible obverse and reverse inscriptions do not match. Most likely this coin is an example of KM\# 56, as the diameter and the detail that is visible on the reverse seems to match the closest for detail and diameter. The standard and official weight provided by Pridmore (1975), de Clermont et al (1986), and Stevens (2012) for the full pai sikka are not wholly consistent, however, archaeologically uncovered numismatic pieces often do not match official production weights. The suspected long period of circulation as evinced by the worn reverse, and the fact that it is an archaeological specimen, likely contribute to the weight being lower than the standard. Paul Stevens (pers. comm.) indicates that the worn reverse may have contributed to its present weight, as he points out the diameter for the 1809 date is consistent. Although this specimen can be identified comfortably to be a pai sikka of the Bengal Presidency, 
due to the damage on the reverse it cannot be dated conclusively to a particular production year. It appears that this coin was likely minted in 1809 as the diameter would indicate, however, due to its worn nature it cannot be read with certainty.

Another possible hypotheses for the reduced weight, coupled with its worn nature, could be due to the change of the standardized weight of the pice. Pridmore states that in 1809 , the weight of the pice was reduced to nine anna, which is equivalent to the Bihar pysa weighing $6.54 \mathrm{~g}$ as referenced in Statement of Copper Pice Issued from the Calcutta Mint from 6th September 1792 to the 20th March 1835. Even with the measures taken, the pice did not reach wide circulation due to its heavy weight when compared to the Bihar pice. According to Regulation $X$, the Calcutta mint was required to produce a pice for the Benares province whose value was 64 per rupee (Thurston 1893, p. 19). Pridmore believes that a request must have been made to reduce the weight even further to promote the circulation of the Calcutta pice within the provinces. He also writes that the 1809 Calcutta pice was identical in regards to the minting process and design to previous ones but weights could vary from 92 to 101 grains (5.96-6.54 g) (Pridmore 1975, p. 210). This specific minting and location of distribution can account for a slightly smaller weight for pai sikka circulated in the Bihar province.

\section{The Ontario House Hotel}

In 1792, Timothy Skinner was assigned the land where the Loretto site was located. This property remained in the Skinner family and was in the possession of the widow Lydia Skinner when the Ontario House hotel was built circa 1823 (Seibel 1987, p. 7). Its proprietorship eventually passed to Colin Skinner sometime in the 1830s. The Ontario House was described as having a "colonnaded front and the three-storey white clapboarded pavilion stood out on the high band above the Horseshoe Falls" (Colonial Advocate 1827). Two watercolor paintings by James Pattison Cockburn show the Ontario House and its neighbour the Pavilion Hotel far in the distance (ROM 942.48.1 and 942.48.2). The paintings reveal the proximity of the two buildings but more detailed plans of the Ontario House do not exist to show layout and specific location within the Skinner property.

The location of the Ontario House was important for it becoming a tourist attraction. It had a view of the Falls and would have been a very tempting rest spot for weary travelers. Stagecoach travel along the Portage Road between Canada and the United States accounted for a substantial portion of the tourism in the area. Niagara Falls eventually became more of a destination spot than a location to stop and rest on a long journey. In 1836, Niagara Falls blossomed as a "honeymoon tourism destination," a trend continued to this day (Seibel 1990, p. 82). The tourism industry played a major part in Niagara Falls' history, as it does now, and many industries were created to cater to the needs of visitors such as coaches, ferries that crossed the river, as well as lodging and food establishments. Yet the Ontario House would never gain the prestige that the more-luxurious Pavilion Hotel would receive, since the Pavilion was considered the heart and social hub of the Niagara Falls area. Reliable published information on the Ontario House is scarce and the lack of published information seems to be a by-product of its less celebrated status. The information that is available discusses the bitter feud between the owner of the Pavilion and the Ontario House. For example, two licenses are recorded granting Colin Skinner the ability to sell liquors and spirits in March 1839 and January 1844 (Graham 1996, p. 87), 
and they are recorded at double the price of other establishments in the area (£7.10). The price reflected the prime location that the Ontario House maintained and resulted in longstanding feuds with the owner of the Pavilion.

\section{The Loretto Site}

The Loretto site settlement pattern comprised several loci that related either to the Ontario House (1823-59), the later Canada House (1859-60), and finally the Loretto Academy (1861+) that was constructed on the property and which was still standing at the time of the 2012 excavation (Hull and MacDonald, p. 56). The pai sikka was found in a buried topsoil in Locus H3 along with artifacts that dated the deposit between the 1820s and 1870s (Hull and MacDonald, p. 56). The artifact types were similar between the loci and reflected the day-to-day activities of the Ontario House occupation (Hull and MacDonald 2014, p. 56). One notable difference was the number of military artifacts and the types of features at Locus H1. The large number of military accoutrements included buttons from the 43rd, 93rd, and 67th Regiments of Foot that were recovered from an open drain. In addition to the significant number of buttons found in the drain, shako plates and chin-strap scales used on British military hats until 1878 (Hull and MacDonald 2014, p. 31) were uncovered. This drain, like many of the features at Locus H1, was contemporaneous with the buried topsoil midden at Locus $\mathrm{H} 3$ where the pai sikka was uncovered, providing evidence as to the layout of the camp. It is believed that the camp tents housing the soldiers were at Locus H1, which would account for the number of military artifacts uncovered there and the minimal examples uncovered in Locus H3 (Hull and MacDonald 2014, p. 56).

\section{Hypotheses on the Pai Sikka's Journey to Canada}

There are three hypotheses on the Ontario House pai sikka's journey to Canada from India and its deposition in a buried topsoil context dated from the 1830s-70s. The first relates to the military background of the Ontario House, the second involves tourist travel to the region, and the last requires an understanding of the shortage of small change in Upper and Lower Canada during the colonial period.

\section{Military Connection}

One possible hypothesis for the deposition of the pai sikka at the Loretto site in Niagara Falls relies on the global movement of troops. During the 1837-38 Rebellion Crisis in the Canadas, British soldiers were introduced to support the Upper Canadian militia to help safeguard the border after a failed attempt to overthrow the Upper Canadian government by William Lyon Mackenzie and his supporters (Seibel 1987, p. 242). It was prudent to place many soldiers along the Niagara River, as there were legitimate fears that unrest would prompt Americans to cross the border and attempt to annex Canada. Thus, in the summer of 1838 , the British military billeted its troops at the Ontario House and other establishments during their service in Drummondville, Upper Canada (now known as Niagara Falls, Ontario) rather than build a barracks. The time 
that the British troops spent in Drummondville was relatively short and lasted from May 1840 until July 1842 (Levinge 1868, p. 145).

According to various sources, both written and cartographic, multiple regiments were housed at the Ontario House. For example, The 1838 Sketch of Drummondville by the Royal Engineers illustrates a variety of landmarks and roads. Important hotels like the Pavilion and the Ontario House were included, as were private homes and barns used to house horses (Fig. 3). It indicated that the Ontario House billeted 200 members of the 43rd Regiment of Foot. Maps of this nature are often produced in times of unrest so that the lay of the land and troop positions were known in case a battle arose.

Evidence also exists for the 93rd Regiment of Foot and the 67th Regiment of Foot's occupation of the Ontario House during the nineteenth century. But only one regiment's length of service in India (the minting place of the pai sikka) allows it to be a candidate for the importation and deposition of this piece. The 67th Regiment of Foot's period in India and its billeting of soldiers at the Ontario House is an intriguing and plausible hypotheses for this coin's migration from its city of minting to its resting place near Niagara Falls.

In the Historical Record of the Sixty-Seventh, The South Hampshire Regiment, Cannon (1849) provides an account of the formation of the regiment and its movements. The 67 th spent 21 years in India and was in Calcutta in 1826 before heading to England. The regiment arrived in Chambly and made its way to Drummondville in May of 1841. The regiment was stationed until the May 19, 1842 and subsequently travelled to Montreal. Orr (1842), a contemporary traveler, described the hotel and the soldiers stationed there in his guidebook. He described the Ontario House as "a large white building, with

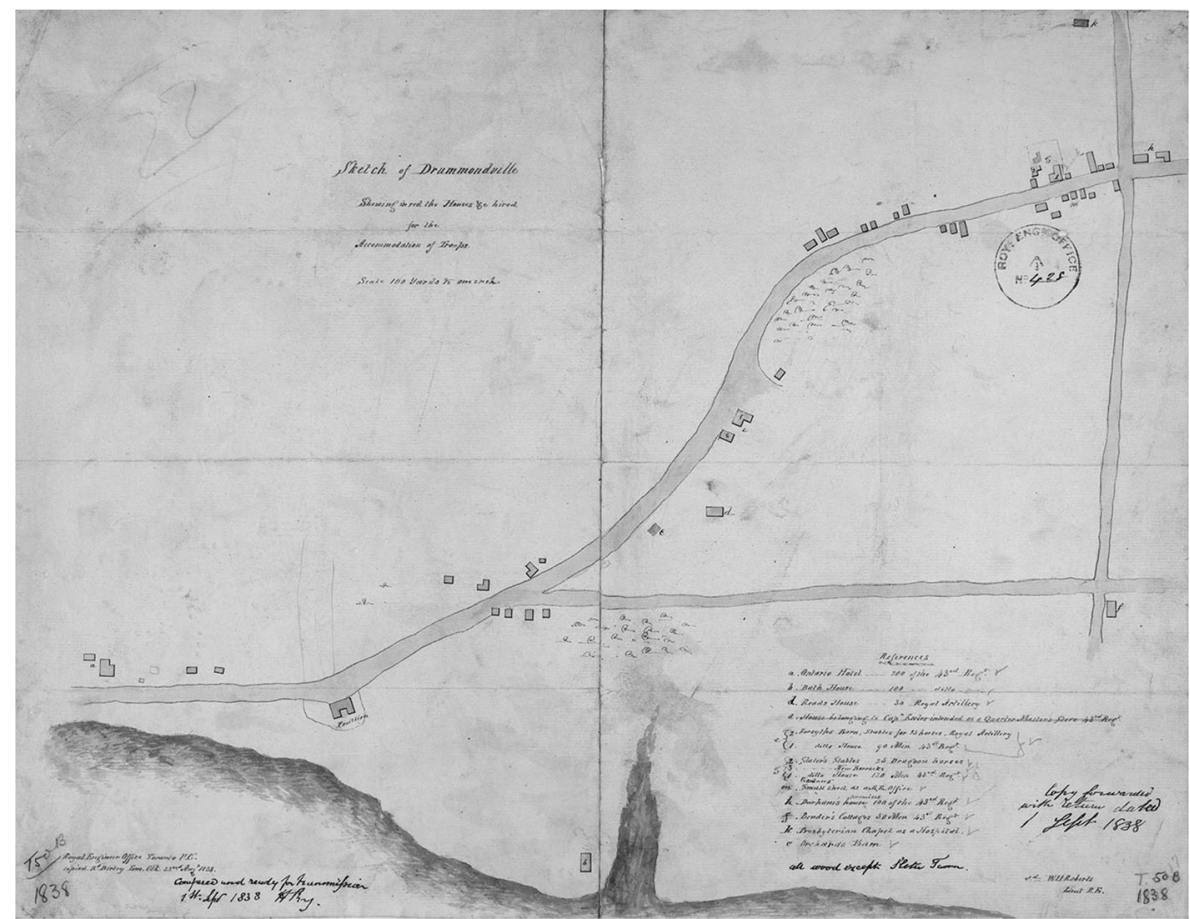

Fig. 3 The Royal Engineers' Sketch of Drummondville 1838 (Library and Archives Canada-NMC 3790, courtesy of Brock University Map Data and GIS Library) 
colonnades in front, about one fourth of a mile above the Falls, formerly kept as a Hotel, when it was called the Ontario House, is now occupied as barracks by the Sixty-Seventh Regiment of Infantry" (Orr 1842, p. 63). Troops of the 67th Regiment of Foot were stationed in India for an extensive period of time. They were billeted at the Ontario House a few decades later and these facts that give weight to the hypotheses that the coin may have been carried by a soldier of the 67 th Regiment of Foot.

The movement of the 67th Regiment throughout India gives a glimpse into where the coin may have been acquired and how it acquired its worn nature. The 67th Regiment of Foot left from Fort William in December 1807 and arrived in Dinapore, India in March of 1808 (Cannon 1849, p. 12). Dinapore is on the right bank of the Ganges in Bihar province and functioned as a garrison town in the nineteenth century. It is about $500 \mathrm{~km}$ from Calcutta and $10 \mathrm{~km}$ northwest of Patna (House of Parliament 1864, p. 293). The regiment remained at Dinapore until January 1810 when they marched for Benares. As referenced above, Bihar province requested the reduced weight pice in 1809 due to its unpopularity and lack of circulation. If this pice is indeed one of the reduced weight variety sent to Bihar province, someone in the regiment could have acquired this piece after the regiment's arrival in Dinapore. Coupled with the worn nature, likely indicating a long period of circulation or transport, there are numerous possibilities as to how it might have been acquired by a soldier in the 67 th Regiment.

The coin could have been picked up in Bihar province while the 67th Regiment was stationed there, requiring the coin to be carried by someone from the regiment for decades without losing it. The suspected date of manufacture, place of distribution, the billeting of the 67th Regiment in Bihar province, and the regiment's occupation of the Ontario House offer some tantalizing possibilities. Although a plausible theory, there are some points which make this lengthy journey with the 67 th less likely. First, it would necessitate that a soldier acquire the coin and then keep it in one purse or circulate it within the unit from ca. 1808 to 1841 , during which time the regiment travelled halfway across the world. All in all, this seems like an inordinate amount of time for a coin of minimal worth to have been husbanded by an owner. That said, the coin could easily have been passed from soldier to soldier, been traded within the regiment, or even acted as a gaming piece. In addition, the coin may have been acquired much later in India, shortening the length of time the piece was carried before its arrival in Canada. It may have been purchased at a bazaar or kept as a souvenir to commemorate their experience of service in India before departing in 1826, or given as change to an unwary soldier sometime during their service.

Although some strong association with the 67 th Regiment seems a plausible way for the pai sikka to have found its way to Niagara Falls, there are other possibilities. The pice could even have been picked up by a soldier serving in India whose regiment never visited Canada, but whose regiment coincided with the 67th Regiment of Foot's service in England, Barbados, or Ireland before its arrival in Canada. There are many hands, regiments, and countries that this coin may have passed through before its deposition at the Loretto site. As there were so many troops serving various lengths of time throughout the world, the ability to exchange items with other soldiers and merchants was quite high. The Ontario House pai sikka may have been one of those items. In the end, the method in which the coin was acquired does not change the importance of this find, as its loss and ultimate recovery has highlighted the strong militaristic past of the Ontario House and the global movement of troops during this period of provincial unrest. 


\section{Tourism}

As briefly discussed above, tourism has long played a major part in the economy of the Niagara Falls region. Even before the mid-1800s, Niagara Falls had become a destination for honeymooners and it drew thousands of others interested in the sublime nature of this world famous natural wonder. Seibel (1990, p. 65) mentions that stagecoach traffic grew steadily after the War of 1812 and increased tourism in the region required more prestigious accommodations for discerning travelers. By 1833, tourists were flocking to the area and the Niagara Gleaner (1833) remarked on the heavy summer tourist traffic between Fort Erie and Niagara Falls. The June 29th edition of the same paper mentioned that six steamers were running weekly between Niagara to ports in Kingston and Prescott and one steamer ran daily to Toronto. The influx of people traveling between Niagara Falls and other cities would have been substantial and the possibility that the pai sikka was lost by a civilian traveler, rather than a soldier, is certainly plausible.

Both the Ontario House and the Pavilion offered quality accommodations and a view of the Falls that many other establishments could not provide. No comparable accommodation could be found on the American side and the pillars of both the Pavilion and the Ontario House were said to be covered with graffiti from newlyweds (Seibel 1990, p. 68). Tourist attractions in the Niagara Falls region at that time included the Terrapin Tower, where for 10 cents one could stand at the edge and overlook the Horseshoe Falls (Strand 2008, p. 68). Stunts designed to draw tourists to the region included Sam Patch's "leap into the Falls" and the rather barbaric sinking of the Michigan which was sent over the Falls with all manner of "ferocious animals" onboard. The latter event was set up by both feuding owners of the Ontario House and Pavilion Hotels (Seibel 1990, pp. 74, 76, 77).

The tourism industry was clearly thriving in the early nineteenth century, while the Ontario House was in operation. The scenery drew people from all over the world and the chance that this coin was brought by a traveler, and then lost while enjoying the view of Niagara Falls from the gardens outside the Ontario House, cannot be understated. Some travelers coming to Canada could and would have traveled to other countries, carrying knick knacks and souvenirs acquired throughout the world.

\section{Canadian Coinage}

The final hypothesis that exists for the journey of the pice is that it was just one of a multitude of small foreign coins often used in Canada. This specimen may have been lost by a tourist, a soldier, a merchant, an employee of the Ontario House or even a local. During the nineteenth century, British colonies were plagued by a lack of hard currency or "specie" that was caused by the external drain of supplies, troops and other necessities for a fledgling country (Redish 1984, p. 724). Innis and Lower (1933, p. 388 ) noted that "one of the chief problems of a new country is to secure and retain a supply of currency. Its wants are so much larger than its production, that as a rule all coin is promptly gathered up by importers to meet their overseas accounts." As a result, colonists were constantly in search of a steady supply of hard currency in order to allow individuals and companies to settle accounts and simply do business of any kind. To highlight the gravity of the situation, at one point in the 1830s, Lord Aylmer sent a letter to the Colonial Office requesting a special copper coinage. Included with this letter was 
a sample of coins currently circulating in neighboring Lower Canada. The "sample" currency included a Royal Fusiliers regimental button (Aylmer to Goderich 1833).

A regular colonial decimal coinage was finally achieved in 1858 , but demands for such an innovation existed as early as the 1820s (Sandham 1869, p. 9). In between those points the early Canadian market was flooded with a variety of coinage including French, American, Spanish, and British pieces (Hudgeons 2009, p. 181). The scarcity of legitimate British small change created a need for pieces that resembled halfpennies for daily commerce. Many coins, especially those that resembled halfpennies, circulated widely in both Lower and Upper Canada. The Wellington halfpenny is an example of a token that circulated even after Confederation in 1867. The Wellington series were, according to Sandham (1869, p. 10), struck in England for the specific purpose of export to any colony that had a scarcity of currency which was affecting local economies. Many of the private tokens and counterfeit pieces circulated in Canada were minted or used pricisely because of the constant shortage of small change that plagued British North American during the nineteenth century (Cross 2010, p. xix).

Various commentators described the bewildering types of coins and tokens passing for legitimate halfpennies in Canada even later in the nineteenth century. For instance, when Sir Duncan Gibb began collecting coins he received "a Greek copper coin of Alexander the Great, in ordinary change from Mr. Peter Dunn, a grocer; a large brass of Domitian, much worn, and another coin of Constantius Chlorus, also in ordinary change, but such occurrences were rare... Spanish, Portuguese and French Silver were the common medium of exchange, associated with that of the U.S.A and Mexico" (Gibb 1874).

As that primary source indicates, Canadian pockets were often filled with currency from all over North America, and indeed the world. Often desperate for any medium of exchange, even privately issued pieces and counterfeit tokens were passed off as legitimate currency. For that simple reason, the pai sikka could have been just another piece used as currency in Canada. Indeed, it should be noted that other out-of-province coins were found at Locus H3 with the pai sikka, including a heavily worn 1814 Nova Scotia Broke Token and an 1820 United States Matron Head Large Cent. Two other pieces were too badly damaged to be identified. The significant amount of small change in one archaeological context would give credence to this hypothesis as all are worn.

This hypothesis places the pice as part of tidal wave of foreign and counterfeit coinage that was commonplace in Upper Canada/Canada West during this time. In this instance the pai sikka would be seen as a less remarkable artifact. Its value was not likely in its use as a souvenir of some sort, but rather as a utilitarian piece of small currency when the colony was desperate for it. As with the other theories, this one cannot be substantiated with certainty, however, the inclusion of other worn currency from other provinces and countries in the same archaeological deposit provides some credence to this hypothesis.

\section{Conclusion}

The recovery of the pai sikka from Lot 7 of Locus H3 of the Loretto Site (AgGs-326) has helped draw attention to the role the Ontario House played during the Rebellion Crisis in the Niagara Region. This area was at the centre of unrest, a popular travel destination, and a travel hub for those voyaging across the international border. Over the years, the Ontario House first accommodated weary and thirsty commercial travelers coming and going to 
the U.S., then played host to lovestruck honeymooners from across the world, and on one occasion, was commandeered by British soldiers sent to keep the Queen's peace. All of these facts added layers of difficulty to the interpretation of a piece like the pai sikka. In the end, of the three theories provided as to the deposition of this piece, no specific hypotheses can be deemed more likely than another. Supportive evidence, both written and archaeological, exists for all three theories.

Of the three hypotheses, the military one seems the most attractive as direct lines can be drawn from its possible acquisition and location of deposition. The large number of military artifacts located in Lot 7 of Locus H1 and the evidence of the 67th Regiment of Foot's prolonged period in India cannot be ignored. But the regiments' stay in India in the early nineteenth century, and its stationing near Niagara Falls decades later, was interrupted by service in England and elsewhere. Nonetheless, one should not underestimate the desire of individuals to cherish a keepsake or hold onto a functional object (e.g. a gaming piece). At the same time, the possibility exists for its deposition by a tourist near Upper Canada's honeymoon hotspot. The large number of stagecoach and ferry passengers would have provided ample opportunity for a well-traveled individual to lose a foreign coin while visiting the Ontario House. The pice's use as regular copper currency when Canada was lacking in small change is feasible and could even function as an offshoot of the other theories; soldiers or travelers carrying the coin and putting it into circulation. Regardless of how it was imported into Canada, investigation of this piece has shed light on a site that was utilized throughout the period in a variety of ways. These ranged from an upscale hotel for travellers, to a honeymoon destination for sightseers, and even a temporary camp for British soldiers during the Rebellion Crisis.

Acknowledgments I would like to thank the following individuals for their advice and assistance with this project: Eva MacDonald (Archaeological Services Inc.), Dr. Katie Hull (Archaeological Services Inc.), Dr. Holt Parker (University of Cincinnati), Dr. Barbara Burrell (University of Cincinnati), Dr. Paul Stevens, Dr. Martin Allen (Department of Coins and Medals, Fitzwilliam Museum), Dr. George Sheppard (Laurentian University), Treya Beaulieu, Chris Thorne and Kristen Hahne. A heartfelt thank you to the anonymous reviewer whose comments and criticisms became an integral part of this work.

Open Access This article is distributed under the terms of the Creative Commons Attribution 4.0 International License (http://creativecommons.org/licenses/by/4.0/), which permits unrestricted use, distribution, and reproduction in any medium, provided you give appropriate credit to the original author(s) and the source, provide a link to the Creative Commons license, and indicate if changes were made.

\section{References}

Aylmer to Goderich (1833). PAC, MG11. Q, Volume 242: 328-334.

Bengal Consultations (1816). November 9. IOR P/9/17, No. 17.

Bengal Mint Committee Proceedings (1817). Letter from Mint Committee to Government, November 10. 1817.IOR P/162/70, No. 46.

Bengal Mint Committee Proceedings (1816) IOR P/162/69, No. 159.

Cannon, R. (1849). Historical Record of the Sixty-Seventh, or the South Hampshire Regiment Containing an Account of the Formation of the Regiment in 1758, and of Its Subsequent Services to 1849, Parker, Furnivall and Parker, London.

Cross, W. K. (2010). Canadian Colonial Tokens, 7th ed., Charlton, Toronto.

de Clermont, André, and Wheeler, John (1986). Spink's Catalogue of British Colonial and Commonwealth

Coins: Standard Reference with Valuations, Spink \& Son Ltd., London. 
Gibb, S. D. (1874). My early experience of numismatics in Canada. Canadian Antiquarian and Numismatics Journal 3(2): 67-73.

Graham, D. R. J. (1996). Inn-Roads to Ancestry: Pioneer Inns in Ontario. In Volume 1: Head of the Lake and Niagara, Ontario Genealogical Society, Toronto.

House of Parliament, and Westminster (1864). Statistical, Sanitary, and Medical Reports for the Year 1862, Harrison and Sons, London.

Hudgeons, M., Hudgeons Jr., T., and Hudgeons Sr., T. (2009). Official Blackbook Price Guide to World Coins, Random House, New York.

Hull, K., and MacDonald, E. (2014). Archaeological Services Inc.: Stage 4 Salvage Excavation of Loci H1 and H3, The Loretto Site (AgGs-326), 6881 Stanley Avenue, Part of Lot 160, Georgraphic Township of Stamford, Welland County, City of Niagara Falls, Regional Municipality of Niagara. Ministry of Tourism, Culture and Sport, Toronto.

Innis, H. A., and Lower, A. R. M. (1933). Select Documents in Canadian Economic History, Porcupine, Toronto.

Krause, C., and Mischler, C. (2004). The Standard Catalogue of World Coins 1801-1900, 4th ed. Krause, Iola.

Levinge, S. R. (1868). Historical Records of the Forty-Third Regiment, Monmouthshire Light Infantry, W, Clowers and Sons, London.

Orr, J. W. (1842). Pictorial Guide to the Falls of Niagara: A Manual for Visitors, Given an Account of this Stupendous Natural Wonder: And All the Objects of Curiosity in Its Vicinity; with Every Historical Incident of Interest: And Also Full Directions for Visiting the Cataract and Its Neighbouring Scenes, Press of Salisbury and Clapp, Niagara Falls.

Pridmore, F. (1975). The Coins of the British Commonwealth of Nations, Part 4, India, Spink and Son, London.

Redish, A. (1984). Why was specie scare in colonial economies? an analysis of the Canadian currency, 17961830. Journal of Economic History 44(3): 713-728.

Revenue Consultations (Opium etc) (1795). Minute of the Governor General (Sir John Shore), October 2. $\mathrm{P} / 89 / 32$.

Ruding, R. (1840). Annals of the Coinage of Great Britian and its Dependencies: From the Earliest Period of Authentic History to the Reign of Victoria. Volume II. J. Hearne, London

Sandham, A. (1869). Coins, Tokens and Medals of the Dominion of Canada, Daniel Rose, Montreal.

Seibel, G. (1987). Ontario's Niagara Parks, A History, revised ed., Niagara Parks Commission, Niagara Falls.

Seibel, G., and Seibel, O. (1990). The Niagara Portage Road; A History of the Portage on the West Bank of the Niagara River 1790-1990, John Leyell and Co. for the Corporation of the City of Niagara Falls.

Stevens, P. (2012). The Coins of the Bengal Presidency, A, H. Baldwin and Sons, London.

Strand, G. (2008). Inventing Niagara: Beauty, Power and Lies, Simon and Schuster, Toronto.

Thurston, E. (1893). Note on the History of the East India Company Coinage from 1753 to 1835, Baptist Mission Press, Calcutta. 